\title{
Fiscal Policy in Developing Countries: A Synoptic View
}

\author{
Raghbendra Jha
}

\begin{abstract}
This paper presents a broad overview of fiscal issues confronting developing countries. Three of these are (i) developing countries have low tax/GDP and expenditure/GDP ratios compared to developed countries, even though developing countries need more public expenditure; (ii) developing country fiscal stance is often pro-cyclical; (iii) developing country tax resources are more volatile than those of developed countries. I also consider the issue of budgetary deficits and problems arising therefrom in developing countries. I then discuss some widely accepted norms for tax and expenditure reforms as also some issues of intergovernmental transfers in federal developing countries.
\end{abstract}

Key Words: Fiscal Policy, tax, expenditure, fiscal transfers.

JEL Classification Number; H20, H24, H25, H63, H77

All correspondence to:

Prof. Raghbendra Jha, Australia South Asia Research Centre, Division of Economics, Research School of Pacific and Asian Studies, Australian National University, Canberra, ACT 0200, Australia

Phone: + 61261252683

Fax: $\quad+61261250443$

Email: r.jha@anu.edu.au. 


\section{Introduction}

Fiscal policy plays an increasingly important role in many developing countries.

Decisions on fiscal policy, especially if properly synchronised with monetary policy, can help smoothen business cycles, ensure adequate public investment and redistribute incomes.

The four main components of fiscal policy are (i) expenditure, budget reform (ii) revenue (particularly tax revenue) mobilization, (iii) deficit containment/ financing and (iv) determining fiscal transfers from higher to lower levels of government. Fiscal policy works through both aggregate demand and aggregate supply channels. Changes in total taxes and public expenditure affect the level of aggregate demand in the economy, whereas, the structure of taxation and public expenditure affect, among others, the incentives to save and invest (at home and abroad), take risks, and export and import goods and services.

This paper presents a broad overview of fiscal issues confronting developing countries. Three of these are (i) developing countries have low tax/GDP and expenditure/GDP ratios compared to developed countries, even though developing countries need more public expenditure; (ii) developing country fiscal stance is often pro-cyclical; (iii) developing country tax resources are more volatile than those of developed countries. These issues are considered in section II of this paper. Section III considers the issue of budgetary deficits and problems arising therefrom in developing countries. Section IV considers some widely accepted norms for tax and expenditure 
reforms and section V considers some issues of intergovernmental transfers in federal developing countries. Section VI concludes.

\section{Tax and Expenditure Profiles of Developing Countries}

The pressures for high and growing government expenditure in developing countries are manifold. Because of their low per-capita incomes and high incidence of poverty, developing countries face an urgency to have high rates of economics growth. This places a strong burden on policy to ensure rapid economic growth whereas, at the same time, the limited efficacy of policy instruments and governance inadequacies imply that the effective scope for policy is constrained. This mismatch between expectations from and actual effectiveness of policy is particularly acute in developing countries, as compared to developed countries. In the former with the perpetual weakness of institutions to mobilize and direct savings, the role of the state is crucial in harnessing resources for development. With weak regulatory apparatus and imperfect market signals, the state plays an important, even dominant, role in allocating investment funds and in anti-poverty programs as well as in their design. Pressures for populism through price controls and the like are considerable.

Concurrently, and for some of the same reasons, states in many developing countries are handicapped in their ability to play an activist role. In most such countries the state is a rather weak political entity than compared to most developed countries. As Heady (2004) notes most developing countries are also beset with lack of consensus on what constitutes a sound fiscal policy. Further, resources available with the government are meagre, since tax bases are small, tax administration weak and tax evasion rampant. 
Table 1 shows tax revenues in different categories of countries: developed, transition and developing for two time periods 1990 to 1995 and 1996 to 2002. In the median developing country the tax/GDP ratio is only 15.7 per cent whereas in the median transition economy it is 25.4 per cent. Developed countries collect almost twice as much as developing countries in tax revenue.

Table 1: Central Government Tax Revenue as a Percentage of GDP, 1990-1995 and 1996-2002 (domestic prices, number of countries and median values)

\begin{tabular}{lcccc}
\hline & \multicolumn{2}{c}{ 1990 to 1995} & \multicolumn{2}{c}{1996 to 2002 } \\
& Countries & Median & Countries & Median \\
\hline Complete Sample & 123 & 20.3 & 111 & 20.2 \\
Developed Countries & 24 & 30.8 & 23 & 31.3 \\
Transitional Economies & 16 & 28.4 & 19 & 25.4 \\
Developing Countries & 83 & 17.3 & 69 & 15.7 \\
Africa & 28 & 19.2 & 22 & 17.4 \\
Latin America \& Caribbean & 25 & 17.3 & 19 & 15.2 \\
Asia \& Oceania & 30 & 16.6 & 28 & 15.2 \\
\end{tabular}

Source: UNPAN Statistics http://www.unpan.org/statistical database-publicsector.asp [accessed 8 February 2007].

What is also remarkable about Table 1 is that developing country collections of tax revenues (as percentages of their GDPs) have come down over time whereas the opposite has happened in the case of developed countries. Hence, on average, governments in many developing countries face a severe resource crunch.

A complication in interpreting Table 1 is that some countries — developed, transition and developing — are federal in nature so that total government revenues outpace central government revenues. Table 2 compares total government tax revenues across these categories of countries. 
Table 2: Total Government Tax Revenue as a Percentage of GDP, 1990-1995 and 1996-2002 (domestic prices, number of countries and median values of the simple averages)

\begin{tabular}{|c|c|c|c|c|c|c|}
\hline & \multicolumn{2}{|c|}{1990 to 1995} & \multicolumn{2}{|c|}{1996 to 2001} & \multicolumn{2}{|c|}{ Direction of Change } \\
\hline & Countries & Median & Countries & Median & Down & Up \\
\hline Separate Samples & 56 & 31.9 & 53 & 33.8 & & \\
\hline Combined Sample & 48 & 33.5 & 48 & 33.8 & 20 & 28 \\
\hline Developed Countries & 21 & 37.8 & 21 & 40.1 & 3 & 18 \\
\hline Transitional Economies & 14 & 34.7 & 14 & 31.4 & 12 & 2 \\
\hline Developing Countries & 13 & 18.7 & 13 & 19.2 & 5 & 8 \\
\hline
\end{tabular}

Source: UNPAN Statistics http://www.unpan.org/statistical database-publicsector.asp [accessed 8 February 2007]

Note: Sum of local plus central government tax revenue

Only 3 of 21 developed countries and 2 of 14 transition countries had revenues coming down over the two time periods whereas the corresponding magnitude for developing countries was 5 of 13. Furthermore, not only are developing country revenues lower than those for developed countries but also the share of distortionary commodity and trade taxes in total central government revenue is higher for developing as opposed to developed countries (Table 3). 
Table 3: Structure of Central Government Revenues

\begin{tabular}{|c|c|c|c|c|c|c|c|c|c|c|c|c|}
\hline & \multicolumn{2}{|c|}{$\begin{array}{c}\text { Taxes on } \\
\text { Income, profits, } \\
\text { and capital gains } \\
\text { ( } \% \text { of revenue) }\end{array}$} & \multicolumn{2}{|c|}{$\begin{array}{l}\text { Taxes on Goods } \\
\text { and Services } \\
\text { (\% of revenue) }\end{array}$} & \multicolumn{2}{|c|}{$\begin{array}{c}\text { Taxes on } \\
\text { international } \\
\text { trade } \\
\text { (\% of revenue) }\end{array}$} & \multicolumn{2}{|c|}{$\begin{array}{l}\text { Other taxes } \\
\text { (\% of revenue) }\end{array}$} & \multicolumn{2}{|c|}{$\begin{array}{c}\text { Social } \\
\text { contributions } \\
\text { (\% of revenue) }\end{array}$} & \multicolumn{2}{|c|}{$\begin{array}{c}\text { Grants and other } \\
\text { revenues } \\
\text { (\% of revenue) }\end{array}$} \\
\hline & 1995 & 2004 & 1995 & 2004 & 1995 & 2004 & 1995 & 2004 & 1995 & 2004 & 1995 & 2004 \\
\hline \multicolumn{13}{|l|}{ Country } \\
\hline Australia & & 62 & & 25 & & 2 & & 2 & & & & 9 \\
\hline Bangladesh & & 12 & & 29 & & 33 & & 4 & & & & 22 \\
\hline Belarus & 16 & 8 & 33 & 36 & 6 & 7 & 11 & 10 & 31 & 35 & 3 & 4 \\
\hline Bolivia & & 7 & & 38 & & 3 & & 13 & & 8 & & 31 \\
\hline Burundi & 14 & & 30 & & 20 & & 1 & & 5 & & 30 & \\
\hline Canada & 50 & 52 & 17 & 18 & 2 & 1 & & & 22 & 23 & 10 & 6 \\
\hline Chile & & 18 & & 45 & & 2 & & 6 & & 6 & & 22 \\
\hline China & 9 & 21 & 61 & 79 & 7 & -8 & 0 & 1 & & & 22 & 7 \\
\hline $\begin{array}{l}\text { Dominican } \\
\text { Republic }\end{array}$ & 16 & 24 & 34 & 41 & 36 & 21 & 1 & 2 & 4 & 3 & 9 & 9 \\
\hline Egypt & 17 & & 13 & & 10 & & 10 & & 10 & & 41 & \\
\hline El Salvador & & 21 & & 41 & & 7 & & 1 & & 14 & & 16 \\
\hline Finland & 21 & 21 & 34 & 35 & 0 & 0 & 2 & 2 & 32 & 30 & 12 & 11 \\
\hline Guatemala & 19 & 25 & 46 & 58 & 23 & 10 & 3 & 1 & 2 & 2 & 6 & 4 \\
\hline Hungary & & 19 & & 36 & & 2 & & 2 & & 33 & & 8 \\
\hline India & 23 & 35 & 28 & 31 & 24 & 14 & 0 & 0 & 0 & 0 & 25 & 19 \\
\hline Jamaica & & 30 & & 34 & & 9 & & 7 & & 7 & & 0 \\
\hline Malaysia & 37 & 47 & 26 & 21 & 12 & 6 & 5 & 0 & 1 & & 19 & 26 \\
\hline South Africa & & 51 & & 35 & & 3 & & 4 & & 2 & & 5 \\
\hline Sri Lanka & 12 & 14 & 49 & 56 & 17 & 12 & 4 & 1 & 1 & 1 & 18 & 16 \\
\hline Tajikistan & 6 & 3 & 63 & 54 & 12 & 11 & 0 & 1 & 13 & 12 & 5 & 18 \\
\hline U.K. & 39 & 36 & 31 & 32 & & & 6 & 6 & 19 & 22 & 5 & 4 \\
\hline U.S. & & 51 & & 4 & & 1 & & 1 & & 40 & & 3 \\
\hline \multicolumn{13}{|l|}{ Low income } \\
\hline \multicolumn{13}{|l|}{ Middle Income } \\
\hline \multicolumn{13}{|l|}{$\begin{array}{l}\text { Lower middle } \\
\text { income }\end{array}$} \\
\hline $\begin{array}{l}\text { Upper middle } \\
\text { Income }\end{array}$ & & 15 & & 34 & & 4 & & 2 & & & & 12 \\
\hline \multicolumn{13}{|l|}{$\begin{array}{l}\text { East Asia \& } \\
\text { Pacific }\end{array}$} \\
\hline $\begin{array}{l}\text { Europe and } \\
\text { Central Asia }\end{array}$ & & 10 & & 36 & & 5 & & 0 & & 33 & & 15 \\
\hline $\begin{array}{l}\text { Latin America } \\
\& \text { Caribbean }\end{array}$ & 16 & & 29 & & 12 & 7 & 3 & & & 10 & 14 & \\
\hline $\begin{array}{l}\text { Middle east \& } \\
\text { North Africa }\end{array}$ & 17 & & 13 & & 15 & & 3 & & & & 36 & \\
\hline South Asia & 11 & 12 & 28 & 29 & 24 & 18 & 2 & 1 & & & 26 & 33 \\
\hline High Income & & & & & & & & & & & & 11 \\
\hline Europe EMU & 23 & 24 & 24 & 24 & 0 & 0 & 3 & 3 & 35 & 37 & 7 & 7 \\
\hline
\end{tabular}

Source: World Development Indicators 2006 
Similar results obtain for broad aggregates of these categories of countries as

Tables 4 and 5 reveal.

Table 4: Central Government Revenue by Type of Tax, 1990-2002 averages (percentage of total tax revenue, median value of simple averages)

\begin{tabular}{|c|c|c|c|c|c|}
\hline & $\begin{array}{c}\text { No. of } \\
\text { Countries }\end{array}$ & $\begin{array}{c}\text { Direct } \\
\text { taxes }\end{array}$ & $\begin{array}{c}\text { Payroll } \\
\text { taxes }\end{array}$ & $\begin{array}{l}\text { Sales } \\
\text { taxes }\end{array}$ & $\begin{array}{l}\text { Trade } \\
\text { taxes }\end{array}$ \\
\hline Complete Sample & 139 & 27.1 & 5.9 & 34.8 & 14.6 \\
\hline Developed Countries & 24 & 34.8 & 28.5 & 28.1 & 0.5 \\
\hline Transitional Economies & 23 & 17.7 & 33.3 & 38.9 & 6.2 \\
\hline Developing Countries & 92 & 27.6 & 0.7 & 33.0 & 24.9 \\
\hline Africa & 32 & 27.2 & 0.2 & 30.7 & 33.0 \\
\hline Latin America \& Caribbean & 27 & 22.1 & 5.1 & 38.9 & 13.7 \\
\hline Asia \& Oceania & 33 & 34.1 & 0.0 & 34.8 & 25.6 \\
\hline
\end{tabular}

Source: UNPAN Statistics http://www.unpan.org/statistical database-publicsector.asp [accessed 8 February 2007].

Table 5: Central Government Tax Revenue by Type, 1990-2002 averages (percentage of GDP, domestic prices, median value of simple averages)

\begin{tabular}{|c|c|c|c|c|c|}
\hline & $\begin{array}{c}\text { No. of } \\
\text { countries }\end{array}$ & $\begin{array}{l}\text { Direct } \\
\text { taxes }\end{array}$ & $\begin{array}{l}\text { Payroll } \\
\text { taxes }\end{array}$ & $\begin{array}{l}\text { Sales } \\
\text { taxes }\end{array}$ & $\begin{array}{l}\text { Trade } \\
\text { taxes }\end{array}$ \\
\hline Complete Sample & 12 & 5.4 & 1.1 & 7.0 & 2.0 \\
\hline Developed Countries & 24 & 9.9 & 8.9 & 8.7 & 0.1 \\
\hline Transitional Economies & 18 & 5.5 & 8.7 & 11.2 & 1.6 \\
\hline Developing Countries & 87 & 4.3 & 0.1 & 5.2 & 3.0 \\
\hline Africa & 30 & 4.6 & 0.0 & 5.2 & 5.0 \\
\hline Asia \& Oceania & 32 & 4.8 & 0.0 & 4.0 & 2.6 \\
\hline Latin America \& Caribbean & 25 & 3.4 & 1.1 & 5.6 & 2.1 \\
\hline
\end{tabular}

Source: UNPAN Statistics http://www.unpan.org/statistical database-publicsector.asp [accessed 8 February 2007].

There are stark difference between developed and developing countries, e.g., trade taxes are much more important in the latter and direct taxes in the former. 
It is instructive to examine that dependence of sources of government revenue on GDP per capita. This is shown in table 6.

Table 6: Sources of Government Revenue (1996-2001)

\begin{tabular}{|l|c|c|c|c|c|c|c|c|}
\hline $\begin{array}{c}\text { GDP per } \\
\text { capita }\end{array}$ & $\begin{array}{c}\text { Tax } \\
\text { revenue } \\
\text { (\% of } \\
\text { GDP) }\end{array}$ & $\begin{array}{c}\text { Income } \\
\text { taxes (\% } \\
\text { of } \\
\text { revenue) }\end{array}$ & $\begin{array}{c}\text { Corporate } \\
\text { income tax } \\
\text { (\% of } \\
\text { income } \\
\text { taxes) }\end{array}$ & $\begin{array}{c}\text { Consumption } \\
\text { \& Production } \\
\text { taxes (\% } \\
\text { of revenue) }\end{array}$ & $\begin{array}{c}\text { Border } \\
\text { taxes } \\
(\% \text { of } \\
\text { revenue) }\end{array}$ & $\begin{array}{c}\text { Inflation } \\
\text { rate (\%) }\end{array}$ & $\begin{array}{c}\text { Seigniorage } \\
\text { Income } \\
\text { (\% of } \\
\text { revenue) }\end{array}$ & $\begin{array}{c}\text { Informal } \\
\text { econom } \\
\text { (\% of } \\
\text { GDP) }\end{array}$ \\
\hline$<\$ 745$ & 14.1 & 35.9 & 53.7 & 43.5 & 16.4 & 10.6 & 21.8 & 26.4 \\
\hline$\$ 746-2,975$ & 16.7 & 31.5 & 49.1 & 51.8 & 9.3 & 15.7 & 24.9 & 29.5 \\
\hline$\$ 2976-\$ 9205$ & 20.2 & 29.4 & 30.3 & 53.1 & 5.4 & 7.4 & 6.0 & 32.5 \\
\hline All developing & 17.6 & 31.2 & 42.3 & 51.2 & 8.6 & 11.8 & 16.3 & 30.1 \\
\hline$>\$ 9206$ & 25.0 & 54.3 & 17.8 & 32.9 & 0.7 & 2.2 & 1.7 & 14.0 \\
\hline
\end{tabular}

Source: Gordon and Li (2005)

Table 6 presents a revealing account of distribution of tax revenue by GDP per capita. In the richest countries personal income taxes are the most significant and contribute more than half (54.3 \%) of tax revenue. Next in line are various commodity taxes and then the corporation tax. Border taxes and seigniorage revenue are low. The latter is reflected in the low value for inflation. The size of the informal economy is low. With falling GDP per capita, however, there is steady deterioration in almost all of these parameters. Tax revenue as a percentage of GDP drops and corporate taxes ads percentage of revenue rise as GDP per capita falls. Income taxes as a percentage of revenue remains within the 30 to 35 percent range. The share of commodity taxes is high. High rate of inflation gets reflected in the high value of seigniorage revenue. The poorest among the developing countries raise almost a quarter of their revenue through seigniorage. The informal sector in developing countries is about twice the size in developed countries. 
The fact that informal sectors are larger in developing as opposed to developed countries has important implications for tax design and effectiveness. Auriol and Warlters (2005) argue that the larger size of the informal sector in developing countries arises from the higher costs of entry into the formal economy in developing countries. The reason for this is that by keeping barriers to entry into the formal economy at high levels those firms and individuals who make it into the formal economy acquire large rents and hence may be easier to tax than a diffused set of small taxpayers. If this argument is correct then encouraging large informal sectors would be part of a government strategy to increase tax revenue. Auriol and Warlters establish the veracity of their theory with empirical analysis covering 64 countries and show that their claim is indeed true, particularly in the case of African countries. For instance, they report that 0.4 per cent of taxpayers account for 61 per cent of total domestic tax collection in Kenya and 57 per cent in Colombia. Keeping this in mind the International Monetary Fund (IMF) has advocated the establishment of large tax units (LTUs) in many developing countries so that tax collection may be facilitated. By concentrating scarce tax administration resources where they are most productive, LTUs would permit the adoption of more sophisticated taxation instruments. Auriol and Walrters argue that developing countries should lower entry barriers and raise the size of the formal sector to get more tax revenues.

Another cause for concern about tax bases in developing countries is the relentless pace of globalization and technological advancement and the accompanying movement of factors of production across national boundaries. Increasingly multinational corporations have become major actors in developing countries since many developing country enterprises have limited capacity to compete. This can lead to substantial erosion of tax bases in many developing countries (Lao-Araya 2003). 
In the face of globalization firms and individuals are freer to adopt global strategies. However, national governments must, perforce, think in terms of domestic allocation of resources, the national account books, increasing the domestic rate of growth, protecting the domestic poor and so on. In this sense, the scope of activities of governments and those of the best and most dynamic firms and individuals are tending to divert from each other more than at any other time in the past. The future has much more of this in store. Thus increased liberalization of financial markets has improved the international allocation of savings and reduced the cost of capital. But it has also widened the opportunities for tax evasion and avoidance. Taxpayers can now raise income outside of conventional channels without the knowledge of the tax authorities. There does not seem to be an easy antidote for this except to encourage rules-based tax laws, good governance and greater cooperation with international taxation bodies.

With inflexible public expenditures and low tax revenues government finances in many developing countries are weak, with high deficits, debts and debt-servicing obligations. Consolidated figures for the finances of central and local governments together are not readily available for many countries but Table 7 presents these for the central governments of select developed, transition and developing countries.

In general for developing countries revenues and expenses are lower and interest payments higher than in developed countries. 
Table 7: Finances of Central Governments for Select Countries

\begin{tabular}{|c|c|c|c|c|c|c|c|c|c|c|c|c|}
\hline & \multicolumn{2}{|c|}{$\begin{array}{l}\text { Revenue } \\
\text { (\% of GDP) }\end{array}$} & \multicolumn{2}{|c|}{$\begin{array}{l}\text { Expense } \\
\text { (\% of GDP) }\end{array}$} & \multicolumn{2}{|c|}{$\begin{array}{c}\text { Cash Surplus or } \\
\text { deficit } \\
\text { (\% of GDP) }\end{array}$} & \multicolumn{4}{|c|}{$\begin{array}{l}\text { Net incurrence of Liabilities } \\
\text { (\% of GDP) }\end{array}$} & \multicolumn{2}{|c|}{$\begin{array}{l}\text { Debt and interest } \\
\text { payments }\end{array}$} \\
\hline & & & & & & & \multicolumn{2}{|c|}{ Domestic } & \multicolumn{2}{|c|}{ Foreign } & \multirow{2}{*}{$\begin{array}{c}\text { Total debt } \\
\text { as } \% \text { of } \\
\text { GDP } \\
2004\end{array}$} & \multirow{2}{*}{$\begin{array}{c}\begin{array}{c}\text { Interest } \\
\text { payment } \\
\text { as \% of } \\
\text { revenue }\end{array} \\
2004\end{array}$} \\
\hline & 1995 & 2004 & 1995 & 2004 & 1995 & 2004 & 1995 & 2004 & 1995 & 2004 & & \\
\hline \multicolumn{13}{|l|}{ Country } \\
\hline Australia & & 26.4 & & 25.5 & & 0.8 & 1.7 & & 0.7 & & 22.4 & 4.0 \\
\hline Bangladesh & & 10.0 & & 8.8 & & -0.7 & & 2.3 & & 0.9 & 36.2 & 16.4 \\
\hline Belarus & 30.0 & 30.6 & 28.7 & 28.5 & -2.7 & -0.2 & 2.2 & 0.7 & 0.4 & 0.5 & 12.3 & 1.5 \\
\hline Bolivia & & 20.2 & & 27.2 & & -5.4 & & 3.6 & & 3.6 & 93.8 & 10.4 \\
\hline Burundi & 19.3 & & 23.6 & & -4.7 & & 3.0 & & 4.0 & & & \\
\hline Canada & 20.6 & 19.9 & 24.6 & 18.3 & -4.4 & 1.4 & 5.0 & -1.0 & 0.0 & 0.3 & 48.7 & 7.9 \\
\hline Chile & & 22.3 & & 18.4 & & 2.2 & & -1.0 & & 0.2 & 15.7 & 4.4 \\
\hline China & 5.4 & 8.8 & & 10.4 & & -2.4 & 1.6 & & & & & 7.6 \\
\hline $\begin{array}{l}\text { Dominican } \\
\text { Republic }\end{array}$ & 16.0 & 16.3 & 10.2 & 13.2 & 0.8 & 1.4 & 0.0 & 1.0 & -1.0 & 2.3 & & 9.4 \\
\hline Egypt & 34.8 & & 28.1 & & 3.4 & & & & & & & \\
\hline El Salvador & & 15.5 & & 17.0 & & -3.3 & & 2.0 & & 0.6 & 49.0 & 14.4 \\
\hline Finland & 40.2 & 39.1 & 38.9 & 36.9 & 1.9 & 2.5 & 0.3 & -0.6 & -1.3 & 3.8 & 45.9 & 4.3 \\
\hline Guatemala & 8.4 & 10.6 & 7.6 & 11.1 & -0.5 & -0.9 & & 0.8 & 0.4 & 1.7 & 19.0 & 10.9 \\
\hline Hungary & & 37.1 & & 41.6 & & -6.2 & & 0.3 & & 5.4 & 58.2 & 210.9 \\
\hline India & 12.3 & 12.6 & 14.5 & 15.9 & -2.2 & -3.6 & 5.2 & 3.6 & 0.0 & 0.3 & 65.8 & 31.9 \\
\hline Jamaica & & 32.0 & 33.3 & 41.1 & & -9.7 & & & & & 145.0 & 59.2 \\
\hline Malaysia & 24.4 & 23.7 & 17.2 & 20.1 & 2.4 & -4.3 & & & -0.8 & & & 10.5 \\
\hline South Africa & & 27.8 & & 29.4 & & -1.9 & & 2.9 & & 0.4 & 36.9 & 12.7 \\
\hline Sri Lanka & 20.4 & 16.4 & 26.0 & 22.9 & -7.6 & -7.6 & 5.2 & 7.0 & 3.2 & 0.1 & 105.5 & 43.6 \\
\hline Tajikistan & 9.3 & 13.5 & 11.4 & 13.8 & -3.3 & -6.6 & 0.1 & -0.2 & 2.3 & 0.2 & 79.8 & 5.1 \\
\hline U.K. & 37.3 & 36.6 & 37.2 & 39.9 & 0.3 & -3.2 & -0.3 & 3.6 & 0.0 & 0.0 & & 5.4 \\
\hline U.S. & & 17.2 & & 20.9 & & -3.8 & & 0.1 & & 3.0 & 38.1 & 11.0 \\
\hline Low income & 13.5 & 13.0 & 15.5 & 15.5 & -2.6 & -3.2 & & & & & & \\
\hline Middle income & 17.3 & & & & & & & 1.1 & & 0.8 & & 9.1 \\
\hline $\begin{array}{l}\text { Lower middle } \\
\text { income }\end{array}$ & 16.7 & & & & & & & 0.9 & & 1.1 & & 8.5 \\
\hline $\begin{array}{l}\text { Upper middle } \\
\text { income }\end{array}$ & & & & & & & & 2.9 & & 0.6 & & 10.5 \\
\hline $\begin{array}{l}\text { East Asia \& } \\
\text { Pacific }\end{array}$ & 8.4 & 11.5 & & 12.0 & & -2.1 & & & & & & 7.6 \\
\hline $\begin{array}{l}\text { Europe \& } \\
\text { central Asia }\end{array}$ & & 31.0 & & 31.1 & & -1.2 & & 0.9 & & 0.4 & & 3.5 \\
\hline $\begin{array}{l}\text { Latin America } \\
\text { \& Caribbean }\end{array}$ & 20.9 & & 23.0 & & -0.4 & & & 1.0 & & 2.3 & & 11.9 \\
\hline $\begin{array}{l}\text { Middle east \& } \\
\text { north Africa }\end{array}$ & 28.3 & & 23.5 & & 0.0 & & & & & & & \\
\hline South Asia & 13.2 & 12.4 & 15.4 & 15.1 & -2.7 & -3.1 & 3.8 & 1.3 & 1.1 & 1.1 & 65.8 & 16.4 \\
\hline High Income & & 26.0 & & 28.9 & & -2.8 & & 1.2 & & & & 6.0 \\
\hline Europe EMU & 36.3 & 35.7 & 38.8 & 38.6 & -2.3 & -2.3 & & 1.1 & & & & 6.4 \\
\hline
\end{tabular}

Source: World Development Indicators 2006 
Table 8: Central Government Expenses

\begin{tabular}{|c|c|c|c|c|c|c|c|c|c|c|}
\hline & \multicolumn{2}{|c|}{$\begin{array}{l}\text { Goods and } \\
\text { Services (\% of } \\
\text { expenses) }\end{array}$} & \multicolumn{2}{|c|}{$\begin{array}{l}\text { Compensation of } \\
\text { employees } \\
\text { (\% of expenses) }\end{array}$} & \multicolumn{2}{|c|}{$\begin{array}{c}\text { Interest } \\
\text { Payments } \\
\text { (\% of expenses) }\end{array}$} & \multicolumn{2}{|c|}{$\begin{array}{c}\text { Subsidies and } \\
\text { other transfers } \\
\text { (\% of expenses) }\end{array}$} & \multicolumn{2}{|c|}{$\begin{array}{l}\text { Other Expenses } \\
\text { (\% of expenses) }\end{array}$} \\
\hline & 1995 & 2004 & 1995 & 2004 & 1995 & 2004 & 1995 & 2004 & 1995 & 2004 \\
\hline \multicolumn{11}{|l|}{ Country } \\
\hline Australia & & 10 & & 10 & & 4 & & 70 & 7 & 5 \\
\hline Bangladesh & & 17 & & 25 & & 20 & & 29 & & 9 \\
\hline Belarus & 39 & 19 & 5 & 13 & 1 & 2 & 55 & 64 & 0 & 3 \\
\hline Bolivia & & 17 & & 24 & & 9 & & 44 & & 5 \\
\hline Burundi & 20 & & 30 & & 6 & & 14 & & 10 & \\
\hline Canada & 8 & 8 & 10 & 11 & 18 & 9 & 64 & 66 & & 6 \\
\hline Chile & & 9 & & 22 & & 5 & & 55 & & 8 \\
\hline China & & & & & & 7 & & 62 & & 0 \\
\hline Dominican Republic & 16 & 16 & 41 & 45 & 9 & 12 & 19 & 15 & 6 & 12 \\
\hline Egypt & 18 & & 22 & & 26 & & 6 & & & \\
\hline El Salvador & & 13 & & 42 & & 13 & & 5 & & 27 \\
\hline Finland & 10 & 10 & 10 & 10 & 9 & 5 & 65 & 68 & 7 & 7 \\
\hline Guatemala & 15 & 12 & 50 & 28 & 12 & 11 & 18 & 21 & 6 & \\
\hline Hungary & & 8 & & 14 & & 10 & & 60 & & 8 \\
\hline India & 14 & 15 & 10 & 10 & 27 & 26 & 33 & & 0 & \\
\hline Jamaica & 22 & 13 & 24 & 32 & 32 & 46 & 1 & 2 & 21 & 8 \\
\hline Malaysia & 23 & 26 & 34 & 30 & 17 & 12 & 27 & 31 & 1 & 1 \\
\hline South Africa & & 12 & 9 & 11 & 13 & 5 & 62 & 65 & 5 & 7 \\
\hline Sri Lanka & 23 & 14 & 20 & 25 & 22 & 32 & 24 & 22 & 10 & 7 \\
\hline \multicolumn{11}{|l|}{ Tajikistan } \\
\hline U.K. & 22 & 19 & 7 & 13 & 9 & 5 & 53 & 53 & 9 & 10 \\
\hline U.S. & & 16 & & 13 & & 9 & & 60 & & 2 \\
\hline \multicolumn{11}{|l|}{ Low income } \\
\hline \multicolumn{11}{|l|}{ Middle Income } \\
\hline \multicolumn{11}{|l|}{ Lower middle income } \\
\hline Upper middle Income & & 13 & & 20 & & 13 & & 50 & & \\
\hline \multicolumn{11}{|l|}{ East Asia \& Pacific } \\
\hline Europe \& central Asia & & 20 & & 16 & & 4 & & 52 & & 8 \\
\hline Latin America \& Caribbean & 14 & 13 & 36 & 29 & 15 & 14 & & 26 & & \\
\hline Middle east \& north Africa & 13 & & 39 & & 13 & & 12 & & & \\
\hline South Asia & 32 & 38 & 23 & 26 & 22 & 12 & 15 & 8 & & \\
\hline High Income & & 10 & & 16 & & & & 61 & & \\
\hline Europe EMU & 7 & 6 & 15 & 13 & 9 & 6 & 59 & 68 & 6 & 5 \\
\hline
\end{tabular}

Source: World Development Indicators 2006 
As percentages of GDP, however, governments of developing countries consume less than their developed country counterparts, as Table 9 indicates. Further, if African countries are excluded from the sample, government consumption in developing countries turns out to be even lower.

Table 9: Government Consumption as a Percentage of GDP, 1990, 1996, 2002 (domestic prices, median values)

\begin{tabular}{|l|c|c|c|c|}
\hline & Number of Countries & 1990 & 1996 & $2002^{[1]}$ \\
\hline Complete Sample & 114 & & 15.3 & 15.7 \\
\hline less transitional economies & 101 & 5.2 & 14.3 & 15.6 \\
\hline Developed Countries & 24 & 18.9 & 19.4 & 19.1 \\
\hline Transitional Economies & 13 & 20.0 & 18.0 & \\
\hline Developing Countries & 77 & 14.2 & 12.7 & 14.0 \\
\hline Africa & 26 & 15.1 & 12.8 & 14.7 \\
\hline Latin America \& Caribbean & 25 & 12.9 & 13.4 & 14.6 \\
\hline Asia \& Oceania & 26 & 12.2 & 11.7 & 13.0 \\
\hline
\end{tabular}

Note: [1] or latest data $(2000,2001)$

Source: UNPAN Statistics http://www.unpan.org/statistical database-publicsector.asp [accessed 8 February 2007].

The analysis above has shown that even as developing countries need more public revenue their ability to raise tax revenues is limited. The most immediate explanation for this is the fact that tax collections are endogenous to the GDP. Indeed as reported in Jha (2006) the unweighted average of tax buoyancy (defined as $\frac{\text { Percentage change intax revenue }}{\text { Percentage changeintaxbase }}$ ) for several developing countries is larger than one, indicating that an expansion of income would lead to an increase in the tax/GDP ratio. Conversely a country with a lower per capita income than another would have a disproportionately lower tax/GDP ratio. However, in addition to the impact of GDP, there exist political economy explanations for the observed low tax/GDP ratios. Thus Gordon and Li (2005) argue that taxation, by its very nature, has to depend on the formal economy, i.e., on the information available from bank records in order to identify 
taxable entities and to measure the amount of their taxable activity. Firms face taxes only to the extent that they conduct transactions through the financial sector. If taxes are too high then it may become profitable for firms to conduct some or all of their activities outside the formal sector, in order to avoid these taxes. In rich countries the intermediary services provided by the financial sector are considerable so there is a high cost of abandoning it and conducting business in the informal sector. However, this is not the case in developing countries. Gordon and Li show that, as a consequence of this, tax revenue as a proportion of GDP is likely to be lower in developing countries than in developed countries. Further, the tax base is likely to be narrow and cover mostly capital-intensive firms that need the financial sector the most. As a consequence the tax structure is likely to be biased towards capital income. Further, tariffs would be used to protect the capital intensive sectors and shortfalls in revenue (from public expenditures) would often be met through seigniorage, hence inflation would be high.

Apart from the characteristics of tax and expenditure in terms of levels discussed above, another important characteristic of fiscal variables in developing countries is their relative instability. Table 10 reports on the coefficient of variation of key fiscal variables in 13 Latin American developing countries as compared to 14 industrialised countries. In terms of all the categories discussed and in both nominal and real terms computed coefficients of variation are much higher (sometimes by multiples) for Latin American developing countries than for industrialised countries. 
Table 10: Coefficients of Variation of Key Fiscal Variables

\begin{tabular}{|l|c|c|c|c|}
\hline & \multicolumn{2}{|c|}{ Nominal } & \multicolumn{2}{c|}{ Real } \\
\hline & $\begin{array}{c}\text { Industrialised } \\
\text { Countries }\end{array}$ & Latin America & $\begin{array}{c}\text { Industrialised } \\
\text { Countries }\end{array}$ & Latin America \\
\hline Total Revenue & 0.15 & 0.55 & 0.05 & 0.14 \\
\hline Current Revenue & 0.15 & 0.56 & 0.05 & 0.14 \\
\hline Non-tax revenue & 0.19 & 0.58 & 0.11 & 0.24 \\
\hline Tax Revenue & 0.15 & 0.56 & 0.05 & 0.17 \\
\hline Total Expenditure & 0.16 & 0.55 & 0.05 & 0.14 \\
\hline Current Expenditure & 0.16 & 0.55 & 0.05 & 0.13 \\
\hline Government Consumption & 0.15 & 0.54 & 0.05 & 0.13 \\
\hline Interest Payment & 0.22 & 0.63 & 0.13 & 0.28 \\
\hline Transfers & 0.17 & 0.58 & 0.07 & 0.20 \\
\hline Capital Formation & 0.17 & 0.57 & 0.14 & 0.22 \\
\hline
\end{tabular}

Source: Bertin-Levecq, S. (2000)

N.B.: $\quad$ 1. There are 13 Latin American and 14 industrialised countries. In the sample 2. The Gavin and Perotti (1997) database is used for the analysis.

Not only are fiscal variables more volatile for many developing countries, it is also the case that the movement of fiscal variables is pro-cyclical. Standard Keynesian models imply that fiscal policy should be countercyclical. During recessions the government should be able to lower taxes and raise public expenditures to 'spend' its way out of the recession whereas during good times, taxes can be raised and public expenditures reduced to reduce chances of overheating of the economy. In contrast to this Keynesian view the 'Ricardian Equivalence’ Hypothesis suggested by Barro (1979) suggests that since rational economic agents make decisions based on perfectly anticipated tax and expenditure policies of the government fiscal policy should essentially remain neutral over the business cycle and respond only to unanticipated changes that affect the government's budget constraint. Thus if Keynesian prescriptions are to be followed then fiscal policy should be counter-cyclical, whereas if Barro type prescriptions were being followed there should essentially be no correlation between the phases of the business cycle and fiscal policy. 
The empirical evidence seems to suggest that for the G-7 countries the correlation between government consumption and outputs is indeed clustered around zero, substantiating the Barro principle. However, for many developing countries fiscal policy is actually procyclical which is neither Keynesian nor of the Barro type. Two plausible explanations for this phenomenon have been mentioned in the literature. The first is that tax bases are so narrow and public expenditure so inelastic in developing countries that tax revenues and expenditures rise during expansionary phases of the business cycle whereas during recessions revenues and expenditures both decline for similar reasons. In addition, Talvi and Vegh (2005) provide an interesting political economy argument, within the Barro tradition, for the procyclical behaviour of fiscal policy in developing countries. They argue that fluctuations in the tax base are much larger in developing countries than in developed countries (see the evidence in Table 9). Under these circumstances full tax smoothing of the Barro-type would require that there be large surpluses during good times. However, the ability to run such surpluses during good times is limited by the fact that public expenditures are inelastic and, when the budgetary position is favourable, there are likely to be considerable pressures for expanding public expenditures which means that fiscal resources may be wasted in enhanced public expenditures on public sector undertakings, subsidies and the like rather than on the retiring of debt as full tax smoothing would require. This potential for misusing resources can be so large that finance ministers in developing countries try to avoid raising large surpluses which they accomplish by lowering taxes or rasing expenditures, or both, thus making fiscal policy procyclical. Deviations from full tax smoothing may thus be an indirect way of resisting pressures for increasing public expenditure. Using a sample of 56 countries (20 developed and 36 developing 
countries) the authors show that for the G-7 countries fiscal policy follows the Barro tax smoothing model whereas for the developing countries such policy has been procyclical.

\section{Fiscal Deficit Issues in Developing Countries}

The exercise of fiscal policy in developing countries has its limits. The combination of low revenues and inelastic expenditures means that expenditures routinely, and even increasingly, outpace revenues. With poor credit and bond markets and downwardly inflexible fiscal expenditures, some of the financing of the resultant deficit spills over onto the external sector and the central bank.

Jha (2004) argues there is considerable heterogeneity in experience with respect to the fiscal deficit, between the middle- and low-income country categories and even within low-income category countries. Indeed, the poorest among the least developed countries (LDCs) are caught in an insidious resource trap (UNCTAD 2000). The relation between per capita income and savings appears no different in these countries than in the presently developed nations. However, because of low per capita incomes, savings are low and, therefore, economic growth is low. UNCTAD (2000) estimates that external shocks have a far more serious effect in the least developed countries than other developing countries. This report shows that the average least developed country economy has, since the 1970s, been exposed to adverse external trade shocks with an impact, in the worst years, approximately double the average of other developing countries.

Since domestic resources are meagre some developing countries opt for external finance. However, such supplies are limited, especially for the poorest countries, although large, stable market economies such as India and South Africa attract 
considerable capital inflows. UNCTAD (2000) argues that the low quantum of external flows to the poorest are related to the 'costs of asset development, risks which are rooted in the vulnerability of the least developed countries to shocks, lack of business support services, weak physical, social and administrative infrastructure, and the small scale of projects' (p. 6). Other sources of funding have also been inadequate. Official aid has been falling and private equity flows go to the best performing economies among the developing and transition countries. Reliance has sometimes to be placed on private loans which, as Harberger (1985) notes, are available at increasingly difficult terms since the domestic resource cost (often underestimated) of servicing these goes up with additional borrowing. Other reasons for differences across developing countries include those in continuity and stability of policy regimes: Zambia, with a high number of policy reversals will be associated with greater risks than Mauritius, which has had a credible and stable policy regime.

Given financing constraints many developing countries have to opt, to a considerable extent, on non-bond (monetary) financing of the deficit. This then establishes a direct links between fiscal policy and the monetary base of the central bank, blurs the distinction between fiscal and monetary policy and compromises central bank independence. If high public expenditure is financed by issuing government bonds there is a possibility of crowding out of private investment. By contrast, low and stable levels of the fiscal deficit by sending a positive message on a government's ability to service its debt, may attract private investors and reduce the risk of economic crises. This, in turn, yields further benefits in terms of higher rates of investment, growth, educational attainment, increased distributional equity and reduced poverty. 
If the link between fiscal deficits and monetary expansion were quantitatively strong, there would be a link between the fiscal deficit and inflation — particularly if seignorage revenues were used to close the budgetary gap. However, in developing countries this association is weak. de Haan and Zelhorst (1990) and Easterly and Schmidt-Hebbel (1993) find a positive correlation between inflation and the fiscal deficit only when the inflation rate is high and there is a clear seignorage motive to get additional revenue from money creation. However, Buffie (1999) argues that this result can be ascribed to the behaviour of the public sector wage cycle and that the relation between the fiscal deficit and inflation remains intact once this is factored out. Once public expenditure is restrained, perhaps as part of an IMF stabilization programme, there is an expectation that any cut in the real wage in the public sector would be reversed once the strictures of the programare lifted. The disinflationary programme, therefore, lacks credibility. Buffie considers two possible cases: (i) The low wage phase is followed by a high wage phase of equal length so that average wage is unchanged over the wage cycle. (ii) The low real wage phase is followed by a return of the real wage to its pre-stabilization level. In the first case, since the market expects the real wage rate to rise, inflation picks up even as the deficit falls. Indeed deficit and inflation could be inversely correlated with high inflation prevailing through the low deficit phase. In the second case this result is weaker and depends upon money and consumption being Edgeworth substitutes. Thus the links between fiscal deficit and inflation remain intact even when there is little observed correlation between the two.

Jha (2004) presents evidence on the unsustainability of fiscal deficits of many developing countries. The approach taken involves ascertaining whether in the longterm public revenue and public expenditure are related in the sense that any excess of expenditure over revenue can be financed by generating budgetary surpluses over a 
long-enough time horizon. In the case of several developing countries this cannot be assured and it is concluded that their budgetary deficits are unsustainable. Along similar lines Mendoza and Ostry (2007) argue that whereas fiscal policy in most countries is responsive to budgetary deficits high debt countries do run a risk of having an unsustainable fiscal stance. They find these countries to be Malaysia, Hungary, Ecuador, Morocco, Panama, Philippines, Indonesia, Bulgaria, Cote d’Ivoire, Egypt, Israel, Jordan, Lebanon, Nigeria and Pakistan. Clearly both transition and developing economies belong to this group.

Jha (2004) also shows that both current account deficits and fiscal deficits are unsustainable among a large number of developing countries In fact it becomes clear that developing countries have considerable difficulties in meeting internal and external deficit sustainability conditions. The fact that external sustainability conditions 0 are hard to meet would imply the need for continual capital inflow in order to keep the balance of payments in equilibrium, necessitating the maintenance of a substantial rate of return wedge between domestic and foreign rates of return. This leads to domestic interest rates being substantially higher than global interest rates and acts as a drag on higher growth making debt servicing harder, which, in turn, exacerbates the problem of internal fiscal deficit.

Even if fiscal deficits are sustainable these could impact on economies. Of particular interest to economists is the impact of fiscal deficits on the prospects for economic growth. The financing of fiscal deficits by reducing the amount of funds available for private investment, commonly known as 'crowding out' could, it is argued, hurt the prospects for economic growth. A contrary view argues that public investment, irrespective of how it is financed, by building infrastructure and providing support 
services creates a more conducive climate for private investment and, hence, improves the prospects for economic growth. Ultimately, thus, whether public deficits impede or spur economic growth becomes an empirical question. In this context Adam and Bevan (2005) examine the relation between fiscal deficits and growth for a panel of 45 developing countries over the period 1970-1999. Public expenditure is permitted to be both growth enhancing as well as growth inhibiting and there are distortionary taxes in place. The government budget is not required to be balanced and fiscal deficits are permitted. It is shown that the impact of the deficit depends upon the mode of financing it. Deficits can be growth enhancing if financed by limited seigniorage but it is likely to be growth inhibiting if financed by domestic debt; and to have opposite flow and stock effects if financed by external loans at market rates. These opposite effects, in turn, define a threshold effect before attaining which fiscal deficit has growth enhancing effects and after which the effects of fiscal deficits are growth inhibiting. For their panel of countries Adam and Bevan find this threshold figure to be around 1.5 per cent of GDP after grants.

\section{Norms for Tax and Expenditure Reforms in Developing Countries}

One of the principal aims of a meaningful tax/expenditure reforms policy would be to bolster the savings and investment rates in the economy in order to raise growth rates. A higher growth rate, it is widely accepted, is the best way to lower poverty over the medium term. Empirical evidence on the determinants of effects of savings among a panel consisting of both developed and developing countries presented by Loayza, Schmidt-Hebbel and Serven (2000a \& b) indicates that most important determinant of savings is the level of per capita income and the rate of growth of the economy. This effect is particularly strong in developing countries. Thus raising the rate of savings and 
the rate of growth of the economy becomes a circular issue — the higher the rate of savings the higher the rate of growth of the economy and the higher the rate of growth the higher the rate of savings at least at low absolute levels of per capita income. Their results also point to the possibility of incomplete Ricardian Equivalence. In other words, a given rise in public savings is accompanied by a less than commensurate drop in private savings. Had Ricardian equivalence obtained, consumers would realize that any increase in public expenditure would be paid for by taxes and adjust private saving commensurately.

Such empirical studies also point to the relevance of the gap between the real rate of return on savings and the discount rate. The role played by the characteristics of the credit market is crucial here. For instance, it has been discovered that savers who are liquidity constrained may be more sensitive to such differentials as opposed to those who do not face such constraints. As financial deepening takes place and fewer consumers remain liquidity constrained, this responsiveness may drop. However, it might also be the case that as consumers become less liquidity constrained they might become less risk averse and opt for investments with higher returns. This might help boost the rate of savings. Thus the impact of the tax structure on savings is of critical importance. A meaningful research agenda on stimulating saving must, therefore, concentrate on estimating effective tax rates (and implied net rates of return) for various sources of income as well as for different sectors. It would then be necessary to ensure the elimination of distorting differences in effective tax rates across sectors as well as assets.

Since the prime determinant of the saving rate appears to be the level and rate of growth of per capita income, all tax-induced distortions that create inefficiencies and 
lower the potential rate of economic growth should be eliminated. Thus there is urgent need for tax reforms. The basic tenets of tax reform are well known and far too elaborate for a complete analysis to be attempted here. These are only briefly stated here.

An important canon of tax reform is that as an economy develops reliance on indirect taxation, as a source of revenue should decline. This is because indirect taxes typically have an excess burden (or deadweight losses) associated with them (Jha 1998, chapter 13). Furthermore efficient indirect taxation (one that minimizes excess burden to the representative consumer, for example) can be quite regressive.1 One can make indirect taxes more progressive by sacrificing some amount of efficiency but the extent of the redistribution possible through such means is quite limited (Sah 1983).

This principle applies to indirect taxes that are differentiated and distortionary. If, however, indirect taxes can be levied on final consumption alone it would be possible to avoid the tax-induced changes in relative prices that characterize production taxes such as excise duties. Then, if consumer utility functions are weakly separable between consumption and leisure, a uniform tax on final consumption goods (say a VAT or, in the case of India, a properly harmonized state and central VAT) would approximate a lump-sum tax. ${ }^{2}$ This would be a superior solution to distortionary commodity taxation. It is implicitly understood that a proper VAT would replace the existing indirect tax structure.

A uniform broad-based consumption tax (such as a VAT) with few exemptions (for goods and services consumed in disproportionately large amounts by the poor), harmonized across levels of government in federal countries and few rates is advocated.

\footnotetext{
${ }^{1}$ Efficient indirect taxation often calls for tax rates to very inversely with the compensated elasticity of demand. This would make them 'regressive'.

${ }^{2}$ Separability of the utility function between goods and leisure would indicate that taxation of goods would have no implications for the labor-leisure choice.
} 
These could be supplemented with excise duties on environmental bads or 'luxuries'. Peak tariff duties and effective rates of protection should be reduced gradually. Such tax reforms could improve the allocation of resources and be administratively simpler. If the tax base admits few exemptions and there are fewer rates, costs of compliance and monitoring will fall. A significant exception to this is the VAT, which requires sophisticated account keeping to net out input costs and exempt exports. Such expertise may be lacking in many developing countries. The credibility of the tax regime is also important and tax reforms should aim for a stable tax environment. Tax reform should be well coordinated and, at all times, be simple. Tariff cuts should be accompanied by an upward revision of VAT rates to compensate for tax revenue.

However, in the particular context of developing countries the implementation of the VAT has to be nuanced. Emran and Stiglitz (2005) show that the standard prescription of reducing trade taxes with a revenue compensating upward revision of the rate of a broad-based VAT is welfare improving only in an economy with no informal sector with all production and exchange activity in the tax net - conditions typically not satisfied in developing countries. CSO (2000) notes that in 1999-2000 as much as 60 per cent of India’s GDP came from the unorganized sector and this sector employed 92 per cent of the labour force! When only the formal sector can be taxed, the introduction of a VAT (or a hike in its rate), far from removing distortions across goods and services, may end up creating a distortion between the formal and the informal sectors and may reduce welfare under plausible conditions. Even broadening the VAT base to include more of the informal sector may reduce welfare (Piggott and Whalley 2001). Along the same lines, recent work (Bibi and Duclos 2007) shows that indirect tax reform must have some significant characteristics in order to reduce poverty. In particular, removing all subsidies may not be a good idea. Second, in some cases increasing taxes on already 
taxed commodities and, concurrently, increasing subsidies on already subsidized commodities may reduce poverty across a wide class of welfare measures. Third, indirect tax reform should not be based solely on efficiency considerations, since redistribution may still play an important role in poverty reduction. Finally, reform rather than removal of subsidy may be more relevant for poverty reduction.

Jha (2006) presents a taxonomy of the extant literature's view on how to fine tune the aforementioned tax reforms distributionally sensitive. Although many results are context specific a general result is that items that are consumed in disproportionately large amounts by the poor and exportables should be taxed at lower rates (or exempted from taxation) including in any VAT.

There is some consensus in the literature that tax structures in developing countries are not particularly progressive. Chu et al. (2004) find that (i) only 13 of the 36 overall tax systems surveyed by them are progressive, seven are proportional, seven are regressive and the rest neutral or insignificant. (ii) Income taxes were progressive in 12 of the 14 cases studied whereas indirect taxes were broadly regressive. The progressivity of direct taxes declined over time in eight cases. This needs attention.

A related principle of tax reform is that the share of direct taxation in overall tax revenue should rise. Within direct taxation, reliance has to be shifted from corporate to income taxes. Since corporate profits are taxed at the level of personal income anyway, the rationale for separate corporate taxes is rather weak. There are only two arguments in favor of corporate taxes: i) as a tax on foreigners' incomes and ii) as a tax on noncompetitive profits. ${ }^{3}$ Within the sphere of income taxation, the rate and exemptions structures need to be rationalized. Tax reform theory advocates taxation of 'full income'

\footnotetext{
${ }^{3}$ In developing countries such as India, corporate tax rates are high essentially as a revenue raising measure. It is much harder to evade corporate as compared to income taxes.
} 
the Haig-Simons definition of which is 'all increases in human and physical capital during a period of time'. One cannot pick and choose the types of income one would like to tax. This canon has, of course, been grossly violated in many developing countries with several categories of income exempt from income taxation, e.g., agricultural income from income taxation in India.

In line with the 'new' public economics of the Nobel laureates William Vickrey and James Mirrlees, the number of income tax brackets should be small, the degree of progression mild and the top marginal tax rate low. These have been adhered to in the some tax reforms program. However, an important canon of optimal direct taxation is also that there be few, if any income sources that are exempt from taxation. In several cases this has not been adhered to. In addition, the ongoing process of globalization, which developing country economies are going through, creates its own avenues for tax exemptions.

Another area of importance for taxation for many developed countries is the conduct of commerce over the internet (e-commerce). Some have argued that it is best to leave out e-commerce from the tax net. It is a nascent industry, they argue, and taxing it would thwart its growth. However, this argument is flawed. There is a rationale for zero customs duties on e-commerce in line with arguments for free trade, but not for zero taxes. If goods traded through e-commerce were not taxed whereas goods traded through ordinary channels are this would be inefficient as well as inequitable. A commodity that is sold in a bricks and mortar store and, therefore, subject to taxation would be deemed to be different if sold through e-commerce and escape taxation. Further, those buying through e-commerce are likely to be the more affluent sections of society. This exacerbates inequity. Furthermore, a policy of not taxing e-commerce would provide 
another avenue for tax evasion. There is U.S. evidence to suggest that sales over the Internet are quite responsive to the failure to collect taxes. Furthermore, given its projected phenomenal rate of growth, if e-commerce is not taxed there will be sharp erosion of the tax bases of governments that primarily levy sales taxes.

It is well recognized that e-commerce presents some formidable challenges for tax administration. Both the origin as well as the destination principles of commodity taxation applied at the subnational level in a country such as India would find it hard to deal with e-commerce. With the physical location of both the buyer and the seller of the commodity in question irrelevant for the transaction, assigning tax liability would be hard. In addition, many goods (such as software) sold through e-commerce are directly downloaded and do not necessarily have a physical presence.

Given the vast scale of anticipated e-commerce transactions, it can safely be said that the smaller the scale of government, the greater would be the difficulty of taxing ecommerce. The central government with its reach throughout the country may find it easier to tax e-commerce than individual state governments, certainly local governments. This further centralization of tax authority and the continued need to further decentralize public expenditures would require the devolution of larger and larger funds to state governments. This would put greater stress on the structure of fiscal transfers necessitating a devolution plan that is transparent, fair and acceptable to all levels of government. This development is a further challenge to federal countries and requires urgent research attention from academics and policy makers.

Another source of worry is the presence of tax havens. The OECD estimates, for example, that during 1985-94 the foreign direct investment by the G7 countries in some tax havens in the Caribbean and South Pacific increased more than five fold to more 
than US\$ 200 billion - an increase well in excess of the growth of total outbound FDI. These concerns extend to transition and developing economies and have probably worsened in recent years. In some such situations what has been called 'a race to the bottom' may ensue with national and/or state governments using tax incentives competitively to attract FDI. Such incentives then interact dynamically with the existing avenues for tax evasion (for example because considerable segments of income are not taxed) to reduce not just current tax revenues but the prospects for higher future tax revenues. In the face of this tax reform, particularly direct tax reform should have a considerable element of international cooperation. But all we have are independent action or bilateral treaties. Direct tax reform must take cognizance of this lacuna.

A related issue is that of the taxation of services. Services have become the dominant sector in many developing countries. But services are hard to tax in developing countries so that the service sector escapes taxation in many developing countries. This is inefficient as well as inequitable. Inequitable because it discriminates between providers of goods and services; inefficient because it has the potential of creating several distortions thus increasing non-labor costs. It is not surprising, that the world over, growth in the most rapidly growing part of services (the so-called FIIRE sector of Finance, Insurance, Internet and Real Estate) creates the fewest jobs per unit of value added. It is for such reasons that major indirect tax reforms in recent times go under the rubric of goods and services tax reform. In the U.S., where state sales taxes have largely exempted services, there is evidence that the phenomenal growth of services is related to their non-taxation. A similar phenomenon is at work in many developing countries. 


\section{Expenditure Reform}

Tax reforms should be complemented with appropriate adjustment of government expenditures. Typically this calls for reduction of current subsidies and augmentation of subsidies for well-defined capital projects. The impact of public expenditure is usually ascertained through an ex-post incidence analysis. The question typically asked, is given some tax or public expenditure: i) who pays or receives the benefits of public spending; ii) how much does everyone receive in accounting terms; iii) how much does everyone receive when taking into account behavioral responses to taxes or the free delivery of public services; iv) what are the indirect effects of the program. Such analyses enable the researcher to ascertain the actual distribution of the amount budgeted as a tax receipt or a public expenditure and helps decide whether public expenditures are worth their cost.

A problem with this methodology is that only existing taxes or public programs may be analyzed. We must evaluate not what does exist but what might exist. This is the theme of benefit incidence analysis. Such analysis is marginal (because it should capture differences from the status quo) and behavioral (because of the need to generate counterfactuals). Such analyses are difficult to carry out in many developing countries.

Addressing behavioral issues — especially labor supply and income generation — is important. But such modeling is difficult in the case of developing countries because direct transfers to households, whether positive or negative, are limited. Further, the distinction between formal and informal labor markets is critical with jobs in the former being subject to some form of rationing.

Delineating expenditure adjustments according to their effects on the poor in developing countries cannot await the development of ex-ante analysis. A good rule of 
thumb would be to delay/reduce the cuts in public expenditure on goods and services that are directly or indirectly of high importance in the poor's budget, for example, coarser types of food, fuel and agricultural subsidies.

An example of a successful expenditure adjustment program comes from Chile (Schkolnik 1992). During 1990-92 there was a sharp drop in government expenditure and Chile adopted the neo-liberal doctrine of development in a rather pure form and cut many social programs. However social programs, to the extent they were retained, focused exclusively on the services of the poor.

Even within the broad category of basic services, however, the selection of programs needs to be sensitive to the type and severity of deprivation. If malnutrition is widespread a program of subsidized nutritional supplements would be more effective than an elementary education scheme. Rudra (2004) establishes that only the education component of public expenditure encourages a more favorable distribution of income in the face of globalization. Thus, when high inequality is a concern expenditure on education should not be cut; but the decision on what expenditure items are pro-poor is country specific (Van de Walle and Nead 1995).

\section{Intergovernmental transfer formula reform in Developing Countries}

Most countries including many developing countries have multi-tiered governments. Many are federal while others have a number of local governments in addition to the central government. The rationale for the existence of multi-tiered governments owes much to the classic statement by Oates (1972), and has been extensively reviewed (e.g., Jha 1998). The special conditions relating to intergovernmental fiscal relations are surveyed, among others, by Fjeldstad (2001) and Bird and Smart (2002). 
Typically the central government in most countries collects far more tax and non-tax revenues than local levels of governments. There are several reasons for this. Two of the most well-known reasons for this are that (i) most taxes with high elasticities of revenue (e.g. income taxes and corporate income taxes) can only be levied meaningfully at the central level and (ii) taxation is often used to address concerns of equity. This can often be defined meaningfully only at the national level. State governments typically tax goods and services (increasingly at rates harmonised with those of the central government) and relatively immobile assets, such as landed property. However, a substantial portion of public expenditure is best carried out by local governments since these are likely to be better aware of peoples' preferences over public expenditure. Hence, there is a structural reason for the existence of a mismatch between revenue and expenditure at both the central and sub-national levels. This is typically bridged through fiscal transfers that the central government makes to lower levels of government.

This transfer formula in developing countries typically involves the following characteristics of the sub-national government to which the transfer is made: (i) population, (ii) departure of average income from national average; (iii) area; (iv) index of infrastructure; (v) tax effort and (vi) fiscal discipline. A review of such formulae is available in Bird and Vaillancourt (1998) and Boadway et al. (2000). In this section I briefly comment on the principal constituents of this formula, assuming that the relative weights on these constituents will often be determined by country-specific circumstances.

It is important to ensure that the determinants of the transfer are not affected by the transfer amount itself. If they are, then, the effects of the transfer amount should be 
netted out. Surely, population, income and area are quite exogenous of the transfers made. However, the same cannot be said of other determinants regularly entering into fiscal transfer formulas, such as an index of infrastructure, and fiscal discipline and tax effort. Presumably, when central funds enter states’ budgets, they become quite fungible. Thus if central grants are used for infrastructure development, the index of infrastructure (a determinant of transfers in many countries) will depend upon the transfers made. Analogously if transfer funds can be used to augment resources for better management and/or expansion of states' tax base, then tax effort (as typically measured). Similar comments apply to the variable 'Fiscal Discipline'. If these criteria are to be used then some method ought to be found to net out their endogenous dependence on the transfers made.

Often some variables are incompletely measured, e.g., tax effort. Typically devolution formulae have defined a state's tax effort as: own tax revenue as a percentage of state domestic product and weighted by the inverse of the per capita income. Now this stipulation ensures that if a poorer state collects more taxes, ceteris paribus, then its valuation in tax effort goes up, vis a vis, a richer state. So the formula rewards 'tax effort' by different states differentially. However, the measurement of tax effort itself can be improved. Own tax revenue as a ratio of state domestic product does not control for differences in tax bases across states. Since agriculture is less taxed than industry in many developing countries a state with a higher proportion of its domestic product coming from agriculture, for instance, will have a lower tax base than a state with a lower proportion of state product coming from agriculture. Other examples of influencing variables can be found and it is important that their effects be netted out in ascertaining 'true' tax effort. Thus the measurement of tax effort should control for factors independently affecting tax effort. Further tax effort may be endogenous to the 
incentive structure, e.g., the greater the share of state expenses met by the central government the lower may be tax effort, properly measured (Jha et al. 1999). It is important to measure poverty by the conventional head count ratio, as opposed to per capita income. If data on tax effort are available over a time period then it is useful to examine whether states' tax efforts are converging over time. If this is not the case, special efforts may need to be taken to identify the laggard states.

The variable 'fiscal discipline' as used in many tax devolution formulae can also be improved upon. Typically fiscal discipline is defined as the improvement in the ratio of a state's own revenue receipts to its total revenue expenditure related to a similar ratio for all states. This ratio is used to measure an index of fiscal discipline in a reference period as compared to a base period. However, in so doing the choice of the base year is critical. Further, the measure used does not correct for differential public debt burdens across states. States with high public debts would, ceteris paribus, have higher current expenditures because of the debt servicing obligations and, therefore, some correction for this should be made. Also the measure does not correct for variations in the activity variable across states. Some form of netting out of debt servicing from current expenditure may be tried and also there should be some form of correction for asymmetric incidence of the business cycle across the country.

This last point underscores the importance of developing indirect measures of fiscal discipline. Recently the literature has emphasized the need to develop such measures (Alesina et al. 1999 and Jones et al. 2000). This literature emphasizes that (i) Ex-ante constraints on deficits at the sub-national levels are conducive to fiscal discipline. Examples include balanced budgets or ceilings on fiscal deficits type requirements. (ii) Top bottom procedures attributing strong prerogatives to the 
government vis a vis the legislature in the approval stage of the budget. This ensures that populist spending diluting budgetary provisions get reduced. (iii) Budgetary procedures should be transparent since even the most stringent budgetary laws can be circumvented by opaque budgetary procedures. Alesina et al. (1999) in particular develop an index of fiscal discipline as answers to ten questions (with appropriate weights). These questions are (i) The existence of constitutional constraints on the fiscal deficit or debt. (ii) The importance of a previously approved macroeconomic program as a constraint on the executive branch during the drafting of the budget. (iii) The degree of borrowing autonomy and the extent of constraints on borrowing. (iv) The extent to which institutions are hierarchical or collegial during the budget preparation stage, including the relative standings of various ministries. (v) Constraints on the legislature regarding amendments to the government's proposed budget. (vi) What happens if the budget is not accepted during the constitutionally approved period of time? (vii) Can the budget be modified after approval by the legislature? (viii) Can the government cut spending after the budget is passed? (ix) What are the conditions for the central government to assume debt originally contracted by other agencies? (x) Borrowing autonomy of the state and local governments. Alesina et al. (1999) show that in an appropriately specified model, this index is a significant determinant of the fiscal deficit. An index similar to that used by Alesina et al. but probably expanded to include state level contingent liabilities, losses of state level public enterprises and the losses of state electricity boards could be used to replace the fiscal discipline index typically used to determine intergovernmental transfers in federal developing countries. 


\section{Conclusions}

The role of fiscal policy in developing countries is as important as it is complex.

Developing countries face the unenviable task of accelerating their rates of economic growth to reduce poverty is a short span of time even as they face greater uncertainty, in the face of globalization, about key elements of their fiscal policy such as the tax base. Furthermore, the exercise of fiscal policy is often circumscribed by increasing pressures from the regulatory and exchange rate regimes in place and subject to considerable pressure from external parameters such as competing countries' tax rates. It would be difficult, for example, for a given developing country to have corporate tax rates very different from its competitors or burden monetary policy with high fiscal deficits which could lead to sharp depreciation of the exchange rate.

Nevertheless, the onus on fiscal policy remains substantial. This paper has outlined some of the major challenges that developing countries face in some key areas of fiscal policy: their tax, expenditure and intergovernmental transfer policies. Even here the treatment has been selective, (e.g., there has been little discussion of corporate taxation and indirect tax harmonisation) in order to provide an overview of the issues involved and an introduction to the literature on these topics. 


\section{REFERENCES}

Adam, C. and D. Bevan (2005) 'Fiscal deficits and growth in developing countries', Journal of Public Economics, 89(3): 571-97.

Addison, T. and A. Roe (2004) Fiscal Policy for Development: Poverty, Reconstruction and Growth, Basingstoke: Palgrave Macmillan

Alesina, A., Hausmann, R., Hommes, R. and E. Stein (1999) ‘Budget institutions and fiscal performance in Latin America’, Journal of Development Economics, 59(2):255-73.

Auriol, E. and M. Warlters (2005) ‘Taxation base in developing countries', Journal of Public Economics, 89(3): 625-46.

Barro, R. (1979) ‘Are Government Bonds Net Wealth?’ Journal of Political Economy, vol.82, pp.1095-1117.

Bertin-Levecq, S. (2000) 'Determinants of fiscal volatility: an empirical investigation of Latin American and industrialized countries', New York University, Department of Economics.

Bibi, S. and J. Duclos (2007) 'Poverty-decreasing indirect tax reforms: evidence from Tunisia’, International Tax and Public Finance, 14(2): 165-90.

Bird, R. and M. Smart (2002) 'Intergovernmental fiscal transfers: international lessons for developing countries', World Development, 30(6): 899-912.

Bird, R. and F. Vaillancourt (eds) (1998) Fiscal Decentralization in Developing Countries, Cambridge: Cambridge University Press.

Boadway, R., Roberts, S. and A. Shah (2000) 'Fiscal federalism dimensions of tax reform in developing countries’, chapter 9 (pp. 171-200) in Perry, Whalley and McMahon (eds), Fiscal Reform and Structural Change in Developing Countries, vol.1, Basingstoke: Macmillan Press Ltd. 
Buffie, E. (1999) 'Public sector wage-cycles and the co-movement of the fiscal deficit and inflation in less-developed countries', Journal of Money, Credit and Banking, 31(4): 785-810.

Catão, P. and M. Terrones (2001) 'Fiscal deficits and inflation: A new look at the emerging market evidence’, IMF Working Paper WP/01/74, International Monetary Fund.

Chu, K., Davoodi, H. and S. Gupta (2004) 'Income distribution and tax and government social spending policies in developing countries', in A. Cornia (ed.) Inequality, Growth, and Poverty in an Era of Liberalization and Globalization, New York: Oxford University Press.

CSO (Central Statistical Organisation) (2000) National Account Statistics, New Delhi.

de Haan, J. and D. Zelhorst (1990) 'The impact of government deficits on money growth in developing countries’. Journal of International Money and Finance, 9 (3): 455-69.

Easterly, W. and K. Schmidt-Hebbel (1993) 'Fiscal deficits and macroeconomic performance in developing countries', World Bank Research Observer, 8 (2): 211-37.

Emran, M. and J. Stiglitz (2005) 'On selective indirect tax reform in developing countries', Journal of Public Economics, 89(3): 599-623.

EIU (Economist Intelligence Unit) (2000) 'Zimbabwe Country Report’, London: Economist Intelligence Unit, September.

Fjeldstad, O. (2001) 'Intergovernmental fiscal relations in developing countries: a review of issues’, Working Paper 2001:11, Chr. Michelsen Institute, Development Studies and Human Rights.

Gavin, M. and R. Perotti (1997) 'Fiscal policy in Latin America’, in B. Bernanke and J. Rotemberg (eds), NBER Macroeconomics Annual 1997, Cambridge, Mass: The MIT Press. 
Gordon, R. and W. Li (2005) 'Tax structures in developing countries: many puzzles and a possible explanation’, Working Paper 11267, National Bureau of Economic Research.

Harberger, A. (1985) 'Lesson for debtor-country managers and policymakers’, in G. Smith and J. Cuddington (eds), International Debt and the Developing Countries. Washington, DC: World Bank, 236-57.

Heady, C. (2004) ‘Taxation policy in low-income countries’, in Addison and Roe (eds).

Jha, R. (1998) Modern Public Economics, London and New York: Routledge.

Jha, R., Chitkara, P., Mohanty, M. and S. Chatterjee (1999) 'Fiscal efficiency in selected Indian states’, Empirical Economics, 24(2): 641-54, reprinted in R. Boadway and B. Raj (eds) (2000) Advances in Public Economics, Heidelberg: Springer.

Jha, R. (2004) 'Macroeconomics of fiscal policy in developing countries', in Addison and Roe (eds).

Jha, R. (2006) ‘Pro-poor Fiscal Policy in the Globalized Economy’, in G.A. Cornia (ed.), ProPoor Macroeconomics: Potential and Limitations, Houndmills, Basingstoke: Palgrave Macmillan

Jones, M., Sanguinetto, P., and M. Tommasi (2000) 'Politics, institutions, and fiscal performance in federal system: an analysis of the Argentine provinces', Journal of Development Economics, 61(2): 305-33.

Lao-Araya, K. (2003) ‘Emerging tax issues: implications of globalization and technology’, ERD Policy Brief No. 16, Asian Development Bank, Manila.

Mendoza, E. and J. Ostry (2007) 'International evidence on fiscal solvency: is fiscal policy ‘responsible’?’ IMF Working Paper 0756.

Loayza, N., Schmidt-Hebbel, K. and L. Serven (2000a) What drives private saving around the world? The Review of Economics and Statistics, 82: 165-81 
Loayza, H., Schmidt-Hebbel, K. and L. Serven (2000b) 'How effective is fiscal policy in raising national saving', The Review of Economics and Statistics, 82: 226-38.

Oates, W. (1972) Fiscal Federalism, New York: Harcourt Brace Jovanovich Inc.

OECD (2000), htttp://www.OECD.org (website for OECD fiscal information).

Piggott, J. and J. Whalley (2001) 'VAT base broadening, self supply, and the informal sector', American Economic Review, 91: 1084-94.

Rudra, N. (2004) 'Openness, welfare spending and inequality in the developing world', International Studies Quarterly, 48: 683-709.

Sah, R. (1983) 'How Much Redistribution is Possible through Commodity taxes?’ Journal of Public Economics, 20: 89-101.

Schkolnik, M. (1992) 'The distributive impact of fiscal and labour market policies: Chile’s 1990-1991 reforms’, Innocenti Occasional Papers, Economic Policy Series, No. 33.

Talvi, E. and C. Vegh (2005) ‘Tax base variability and procycilcal fiscal policy in developing countries', Journal of Development Economics, 78(1): 156-90.

UNCTAD (2000) The Least Developed Countries 2000 Report, Geneva: UNCTAD.

Van de Walle, D. and K. Nead (eds), (1995) Public Spending and the Poor: Theory and evidence, Baltimore, Maryland: John Hopkins University Press for the World Bank.

World Development Indicators (2006) 